\title{
Program Pelatihan Sistem Electronic Fuel Injection (Efi) Mobil bagi Siswa SMKN 1 Kecamatan Luak, Kabupaten 50 Kota
}

\author{
Wagino $^{1}$, Bahrul Amin ${ }^{2}$, Wanda Afnison*)3 ,Hendra Dani Saputra ${ }^{4}$ \\ ${ }^{1234}$ Teknik Otomotif/ Fakultas Teknik/ Universitas Negeri Padang \\ *)Corresponding author, $\equiv$ wandaafnison@ft.unp.ac.id
}

Revisi 29/10/2019;

Diterima 30/11/2019

Publish 10/01/2020

Kata kunci: Electronic

Fuel Injection,

Kompetensi,

Workshop

\begin{abstract}
Abstrak
Salah satu permasalahan sekolah di daerah adalah keterbatasan akses informasi dan update teknologi yang cenderung lambat. Kondisi ini diperparah dengan keterbatasan peralatan sertaketersediaan fasilitas praktikum. Kondisi ini menjadi latar belakang penulis bersama tim untuk melaksanakan pengabdian masyarakat di SMK N 1 Kec. Luak. Kondisi sekolah yang masih tergolong baru menyisakan banyak permasalahan dalam kegiatan PBM. Mulai dari ketersediaan peralatan, ketersediaan sumber informasi dan update teknologi yang minim. Kegiatan PKM dilaksanakan selama 4 hari dengan materi system bahan bakar injeksi (EFI). Materi ini dipilih karena permintaan sekolah yang memang masih minim informasi terkait sistem EFI. Kegiatan PKM dimulai dengan kegiatan pre test.di awal pertemuan, yang digunakan untuk pemetaan kompetensi siswa. Kegiatan PKM dibagi menjadi 2 kegiatan utama yaitu: teori dan praktik. Peserta dibekali materi teori terlebih dahulu sebelum melakukan praktik di workshop. Pada akhir kegiatan dilakukan post test sebagai bentuk evaluasi berupa ujian tulis.Dari hasil evaluasi diperoleh peningkatan pemahaman siswa terkait materi system bahan bakar injeksi (EFI) dengan rata-rata peningkatan pemahaman sebesar $10-15 \%$ tiap siswa. Kondisi ini cukup posistif mengingat kegiatan PKM yang dilaksanakan hanya 4 hari. Penulis berkeyakinan jika ini dilanjutkan secara terus menerus maka dapat berdampak kepada peningkatan kualitas PBM dan kualitas lulusan.
\end{abstract}

\section{PENDAHULUAN}

\section{Analisis Situasi}

SMK N 1 Kec Luak merupakan salah satu sekolah kejuruan yang berada di Kabupaten 50 Kota. Terletak di kenagarian Andaleh, sekitar $15 \mathrm{Km}$ dari pusat kota Payakumbuh. SMKN $1 \mathrm{Kec}$ Luak baru berdiri sejak tahun 2008 (11 tahun) namun perkembangannya bisa dikatakan cukup 


\section{Suluah Bendang: Jurnal Ilmiah Pengabdian Kepada Masyarakat}

Vol.20, No.1,2020

Wagino, Bahrul Amin, Wanda Afnison, Hendra Dani Saputra

bagus. Dari awal yang hanya terdiri dari 3 Jurusan, sekarang SMK N 1 Kec. Luak sudah memiliki 7 Jurusan yang terdiri dari jurusan tata boga, busana, multimedia, teknik kendaraan ringan, teknik sepeda motor serta jurusan bisnis dan pemasaran. Semenjak berdiri sampai sekarang, SMK N 1 Kec. Luak menunjukan grafik perkembangan yang sangat pesat, ini dikarenakan letak SMK N 1 Ke. Luak berada pada posisi yang strategis dan berada disekitar penduduk yang memiliki popolasi yang padat. Kondisi ini menjadikan SMK N 1 Kec Luak menjadi salah satu destinasi pendidikan kejuruan yang favorit.

Status sebagai salah satu SMK favorit disekitar Kec. Luak, SMK N 1 Kec. Luak juga didukung dengan luas lahan yang lebih dari cukup, sekitar $152.302 \mathrm{~m}^{2}$. Diatas lahan seluas ini berdiri bangunan dan fasilitas sekolah yang mampu menunjang PBM. Mulai dari workshop untuk setiap jurusan, lapangan olahraga, mushola, kantin dan fasilitas kesehatan juga ada di sekolah ini.

Meskipun demikian, tingginya minat siswa untuk sekolah di SMK N 1 Kec. Luak menyisakan beberapa permasalahan terkait ketersediaan peralatan praktik. Seringkali jumlah peralatan untuk praktik tidak sebanding dengan jumlah siswa yang ada, sehingga berdampak terhadap kualitas PBM. Kondisi ini sebetulnya selalu diupayakan oleh pihak Kepala Sekolah beserta jajarannya, mulai dari pengajuan bantuan ke pemerintah pusat, prov \& daerah. Tapi memang sampai detik ini usaha pihak sekolah belum sampai pada kondisi ideal. Berikut beberapa dokumentasi kondisi SMK N 1 Kec. Luak.
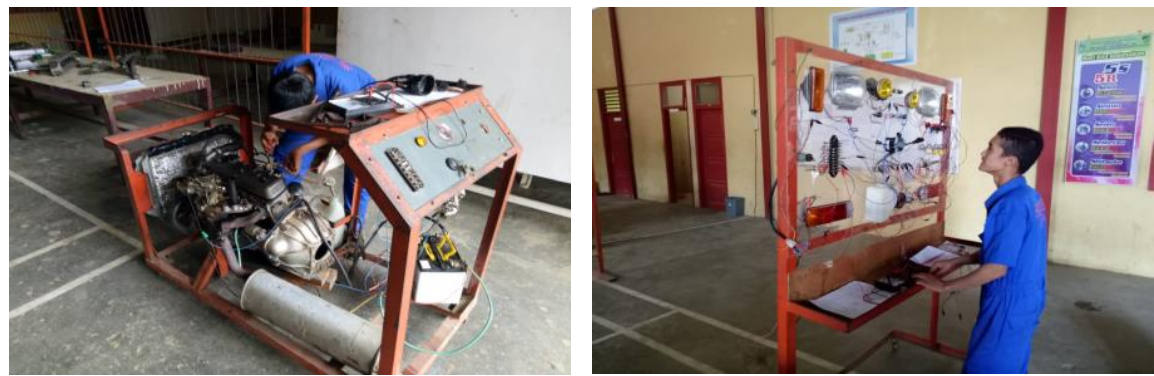

Gambar 1: Fasilitas Praktikum SMK N 1 Kec Luak

Selain permasahan jumlah peralatan, kualitas peralatan yang digunakan dalam praktikum bisa dikatakan jauh dari standar. Dalam praktikum dan bahkan ujian kompetensi, siswa SMK N $1 \mathrm{Kec}$. Luak praktik dengan peralatan yang terkesan seadanya. Setelah di konfirmasi kepada Ka Bengkel Teknik Kendaraan Ringan mengatakan bahwa kondisi ini sudah dilaporkan sejak 2 tahun yang lalu, tapi memang belum ada tindakan. Bahkan pada beberapa tahun sebelumnya, siswa SMK N 1 Kec. Luak harus melakukan Ujian Kompetensi dengan meminjam peralatan ke sekolah lain. Kondisi seperti ini tentunya akan berdampak kepada rendahnya kualitas lulusan dan reputasi sekolah kedapan. Berikut dokumentasi terkait ketersediaan peralatan praktikum:
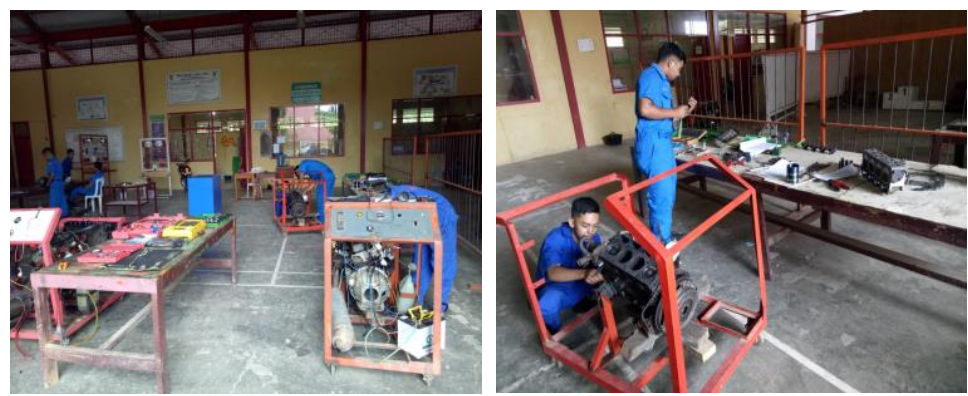

Gambar 2: Peralatan praktikum siswa yang jauh dari standar 
Berdasarkan sejumlah permasalahan diatas pengusul mengajukan proposal pengabdian masyarakat dengan tema pelatihan system bahan bakar Electronic Fuel Injection (EFI) pada mobil. Sistem bahan bakar injeksi (EFI) merupakan salah satu teknologi terbaru di bidang otomotif yang banyak digunakan dan sangat dibutuhkan di dunia usaha/industry. Di sisi lain kompetensi siswa terkait system bahan bakar injeksi (EFI) masih tergolong rendah. Diharapkan dengan adanya program pengabdian ini mampu meingkatkan kualitas belajar mengajar dan meningkatkan kualitas lulusan nantinya.

\section{Solusidan Target}

Dari beberapa msalah yang ditemui di sekolah mitra PKM, pengusul merumuskan beberapa solusi sbb:

1. Pada Program Kemitraan Masyarakat (PKM)ini yang menjadi fokus utama adalah transfer of knowledge teknologi terbaru otomotif. Ini merupakan salah satu permasalahan utama pada sekolah mitra. Pada kegiatan ini akan diberikan pelatihan tentang teknologi terbaru mobil dengan system Electronic Fuel Injection (EFI), penggunaan scan tool untuk identifikasi kerusakan,pemberian materi tentang teknologi ABS dan teknologi terbaru otomotif lainnya.

2. Melaui kegiatan Program Kemitraan Masyarakat (PKM), siswa akan mendapatkan hal baru dalam kemajuan teknologi otomotif. Tidak hanya sampai disana siswa juga dapat mempraktekannya langsung pada sesi kegiatan praktikum. Sehingga dapat dipastikan kegiatan ini mampu meng Up-date pengetahuan/kompetensi siswa.

3. Pada kegiatan ini juga akan dibekali dengan penggunaan alat ukur digital.Ini menjadi wajib karena hampir seluruh sistem pada mobil terbaru menggunakan alat ukur digital sebagai pendeteksi kerusakan dan peformanya.Jadi dapat dipastikan tanpa pengetahuan penggunaan peralatan ukur digital siswa tidak bisa berbuat banyak dalam menyelesaikan permasalahan pada kendaraan

4. Selama berlangsungnya kegiatan Program Kemitraan Masyarakat (PKM),siswa diberikan panduan berupa materi pelatihan dan jobsheet dalam bekerja.Sehingga setiap detail proses pekerjaan dapat dilakukan dengan baik danterukur

Adapun target dari tim PKM adalah terjadinya peningkatan pemahaman dan kemampuan (skill) siswa SMK N 1 Kecamatan Luak dalam menguasai materi system bahan bakar EFI.

\section{METODE PELAKSANAAN}

Untuk mendapatkan hasil yang optimal dari kegiatan ini, pengusul merancang tahapan kegiatan PKM meliputi: pretest, teori,praktikum dan diakhiri dengan evaluasi. Berikut detail masing-masing proses:

1. Pre Test

Tahapan awal yang dilakukan adalah Pre Test. Pada tahap ini pengusul melakukan pemetaan kemampuan peserta terhadap materi yang akan diberikan. Data ini dijadikan acuan untuk materi dan metode pelatihan yang akan diberikan.

2. Pembekalan konsep teori system bahan bakar injeksi (EFI).

Padasesi ini peserta diarahkan kedalam kelas (teori).Kegiatan ini akan diisi dengan materi tentang perkembangan dan kemajuan teknologi terbaru sepeda motor. Pemateri akan berdiskusi dan share informasi terkait perkembangan teknologi otomotif. Demikian juga dengan materi penggunaan alat ukur digital yang diperlukan untuk mengidentifikasi kerusakan pada mobil. Kegiatan ini menjadi dasar/pengantar bagi kegiatan praktikum yang akan dilakukan peserta.

3. Praktikum

Program Pelatihan Sistem Electronic Fuel Injection (Efi) Mobil bagi Siswa SMKN 1 Kecamatan Luak, Kabupaten 50 Kota | 3 Available online: http://sulben.ppj.unp.ac.id 


\section{Suluah Bendang: Jurnal Ilmiah Pengabdian Kepada Masyarakat}

Wagino, Bahrul Amin, Wanda Afnison, Hendra Dani Saputra

Peserta akan diberikan materi tentang SOP pengoperasian alat danbagaimana proses identifikasi kerusakan pada kendaraan.Pada sesi ini peserta sudah dibekali dengan jobsheet untuk dapat mengamati setiap proses pada job sheet dengan detail.Setelah peserta leluasa mengamati proses pada sesi dimulai maka pada bagian ini peserta diberi kesempatan untuk mempraktikan sendiri materi yang sudah ada pada joobsheet tetap dengan pengawasan dan bimbingan instruktur. Pada bagian ini peserta dituntut untuk mengikuti setiap point pekerjaan guna menjamin kualitas pekerjaan.

4. Evaluasi

Setelah seluruh proses dilalui maka kegiatan ini diakhiri dengan proses evaluasi(ujian)teori dan praktik. Langkah ini dilakukan untuk mengukur penguasaan peserta terkait materi yang diberikan. Skor pada proses evaluasi menjadi acuan ada/tidaknya peningkatan kemampuan peserta.

\section{HASIL DAN PEMBAHASAN}

Kegiatan Pengabdian Kepada Masyarakat ini melalui beberapa tahapan pelaksanaan(Penyusun, Penelitian, Pengabdian, Masyarakat, \& Masyarakat, 2019), mulai dari tahapan persiapan, keberangkatan, pelaksanaan dan evaluasi kegiatan. Berikut detail tahapan kegiatan PKM:

\section{A. Proses Persiapan Kegiatan Pkm}

1) Survey Lokasi

Kegiatan awal yang dilakukan adalah melakukan survey lokasi yang dilaksanakan di SMK N 1 Kec. Luak. Kegiatan ini dilakukan untuk mengetahui keadaan lokasi yang meliputi jarak tempuh, medan jalan dan lingkungan masyarakat tempat dilaksanakannya program pengabdian. Pada tahap ini utusan tim pengabdian juga bertugas melakukan komunikasi dengan pihak sekolah dan pemetaan masalah terkait permasalahan PBM yang ada di SMK N 1 Kec. Luak terutama terkait teknologi Sistem Bahan Bakar Elektronik (EFI).

2) Pembuatan Kesepakatan Kerjasama Mitra

Setelah tim menemukan fakta permasalahan di lapangan kemudian tim berkoordinasi dengan pihak Sekolah terkait rencana pengabdian masyarakat. Alhamdulillah respon yang baik kami peroleh dari pihak Sekolah. Kepala Sekolah SMK N 1 Kec Luak bersedia menjadi mitra kami dalam kegiatan Pengabdian Masyarakat. Hasil koordinasi ini berupa agenda kegiatan yang sudah disepakati oleh kedua belah pihak.

Tabel 1: Agenda kegiatan

\begin{tabular}{|c|c|c|c|c|c|}
\hline No & JADWAL & AGENDA KEGIATAN & PENGELOLA & PESERTA & NARASUMBER \\
\hline \multirow[t]{12}{*}{1} & \multirow{12}{*}{$\begin{array}{l}\text { Hari } \\
\text { pertama: } 7 \\
\text { Agustus } \\
2019\end{array}$} & \multirow{12}{*}{$\begin{array}{l}\text { - } 08.00 \text { - } 09.30 \\
\text { Pembukaan kegiatan } \\
\text { dan pre test } \\
\text { 09.30-12.20 } \\
\text { Materi dasar system BB } \\
\text { EFI } \\
\text { - } 13.30 \text { - } 15.00 \\
\text { Sensor dan } \\
\text { kelengkapan Sistem BB } \\
\text { EFI } \\
\text { 15.00 - } 16.30 \\
\text { Prinsip dan cara kerja }\end{array}$} & \multirow{12}{*}{$\begin{array}{l}\text { Wagino, S.Pd, } \\
\text { M.Pd.T } \\
\text { Wanda } \\
\text { Afnison, M.T }\end{array}$} & \multirow[t]{12}{*}{ 180rang } & 1. M. Yasep \\
\hline & & & & & Setiawan, \\
\hline & & & & & M.T \\
\hline & & & & & 2. Nuzul \\
\hline & & & & & Hidayat, M.T \\
\hline & & & & & 3. Dedi \\
\hline & & & & & Mulyono \\
\hline & & & & & (Mahasiswa \\
\hline & & & & & JT0) \\
\hline & & & & & 4. M. Faiz \\
\hline & & & & & Saputra \\
\hline & & & & & (Mahasiswa \\
\hline
\end{tabular}




\begin{tabular}{lll}
\hline 2 & Hari & $\bullet 08.00-12.20$ \\
& kedua: 8 & Trouble shooting \\
& Agustus & system BB EFI \\
& 2019 & $\bullet 13.30-16.30$ \\
& & Tune-up kendaraan \\
& & dengan sistem BB EFI \\
\hline 3 & Hari ke & $\bullet$ 08.00 - 12.20 \\
& tiga: 9 & Uji Emisi gas buang \\
& Agustus & system BB EFI \\
& 2019 & $\bullet 13.30-16.30$ \\
& & Injector cleaner \\
\hline 4 & Hari ke & $\bullet$ 08.00 - 16.30 \\
& empat: 10 & Uji kompetensi dan \\
& Agustus & evaluasi kegiatan \\
& 2019 &
\end{tabular}

\section{B. Proses Pelaksanaan Kegiatan Pkm}

a) Proses Keberangkatan Tim menuju Lokasi PKM

Tim PKM berangkat menuju lokasi satu hari menjelang kegiatan. Tim menggunakan dua kendaraan menuju lokasi dimana satu mobil mengangkut Tim PKM sedangkan lainnya membawa engine stand untuk persiapan praktikum di lokasi.

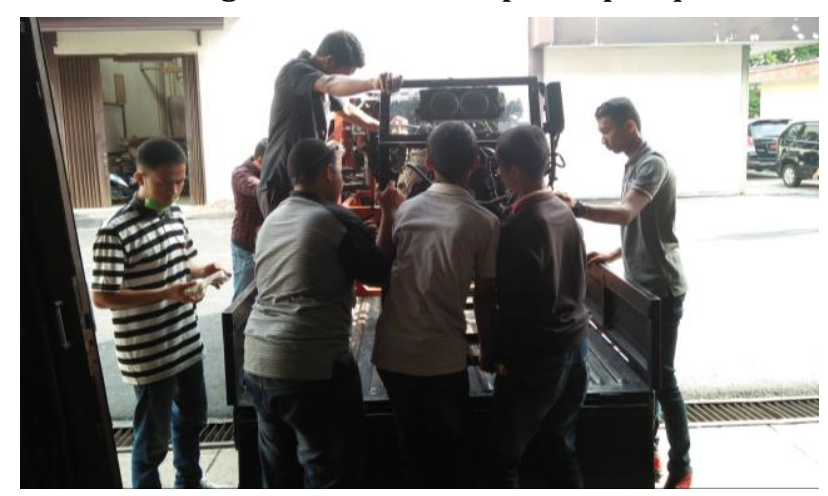

Gambar 3: Tim bersiap berangkat ke lokasi PKM

b) Pembukaan Kegiatan PKM

Kegiatan PKM dilaksanakan pada tanggal 7-10 Agustus 2019. Pembukaan kegiatan dilaksanakan pada tanggal 7 Agustus yang berlokasi di SMK N 1 Kec. Luak. Kegiatan ini dihadiri Kepala Sekolah dan anggota pelatihan.

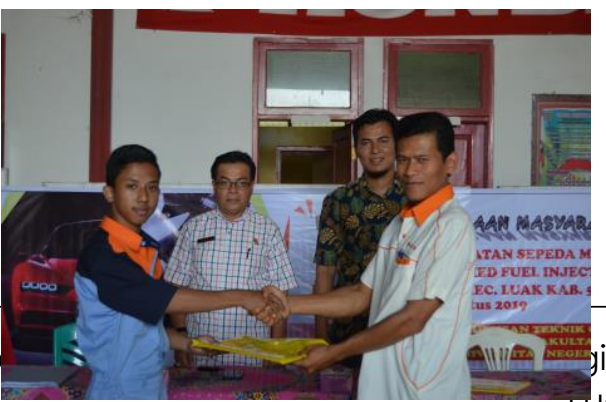




\section{Suluah Bendang: Jurnal Ilmiah Pengabdian Kepada Masyarakat}

Gambar 4: Penyerahan ATK secara simbolis kepada salah seorang peserta

c) Pre test

Sebelum pelatihan dilaksanakan, kami dari Tim PKM melakukan test awal[5] guna mengetahui sejauh mana penguasaan peserta terkait materi yang akan diberikan. Ini berfungsi segabai pemetaan awal sehingga menjadi acuan bagi Tim PKM untuk mempersiapkan materi dan metode yang sesuai agar kegiatan pelatihan dapat berjalan sebagaimana mestinya.

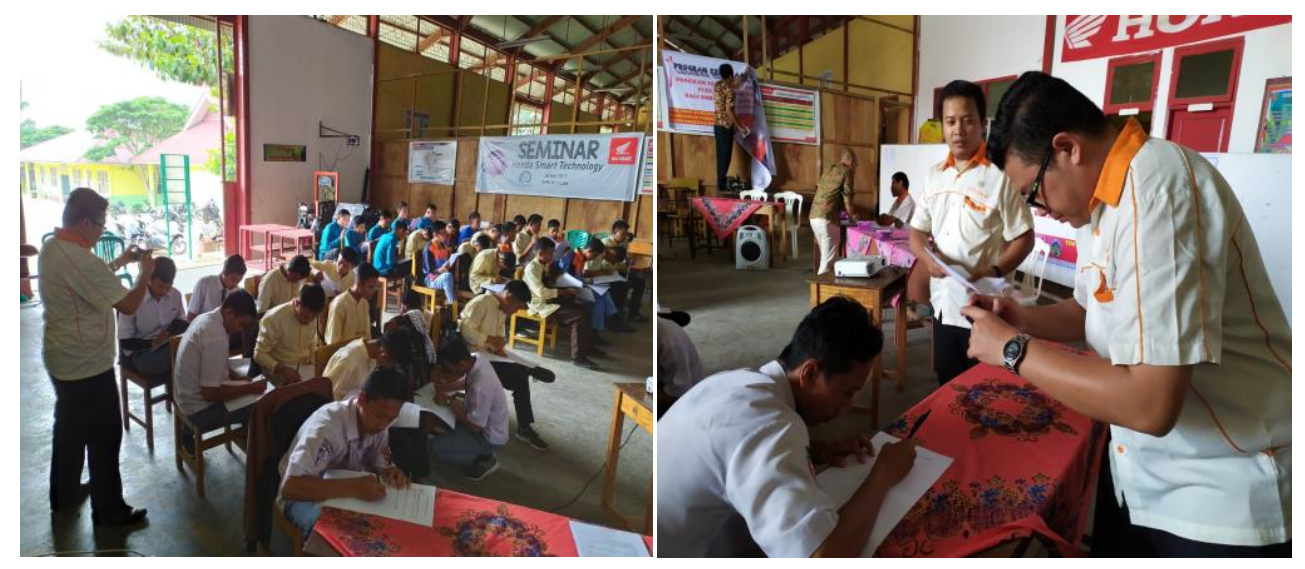

Gambar 5. Pre Test jelang kegiatan pelatihan dimulai

Dari hasil pre test terlihat bahwa kemampuan peserta masih kurang terkait System Bahan bakar Injeksi (EFI). Berikut grafik nilai siswa pada hasil pre test.

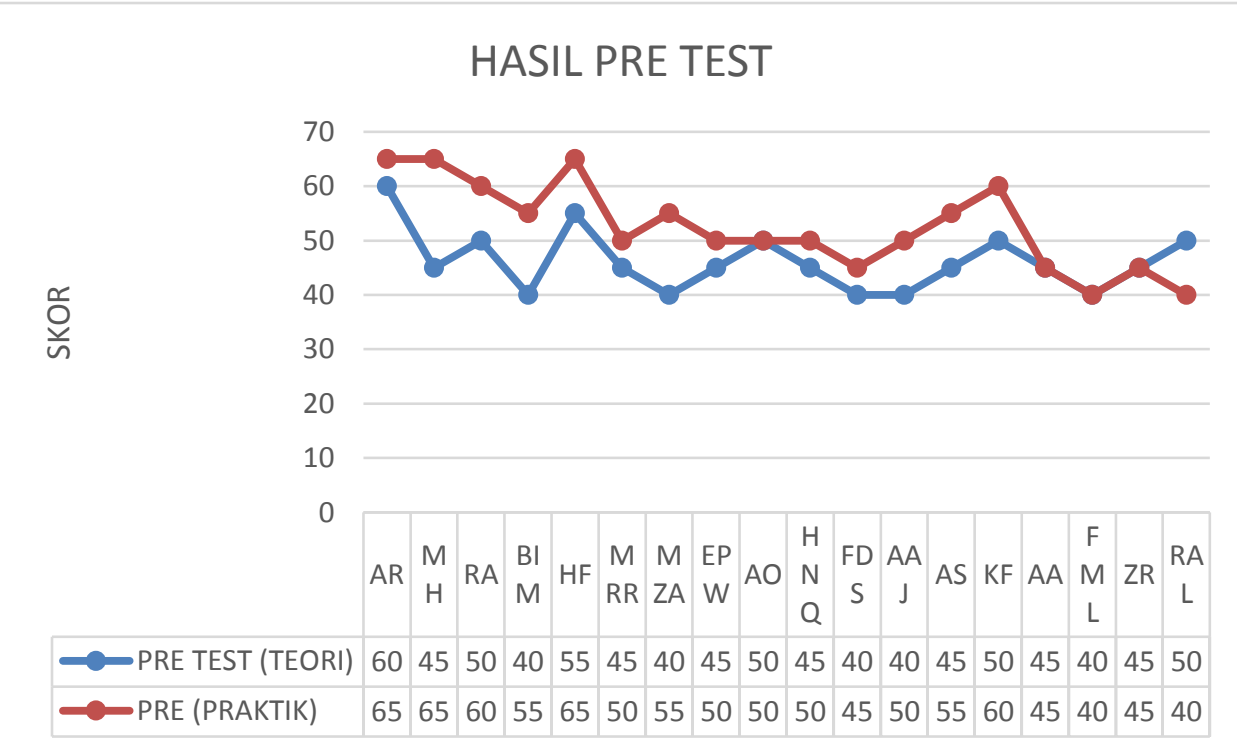

Available online: http://sulben.ppj.unp.ac.id| 6 
Grafik 1. Hasil pre test peserta jelang kegiatan

d) Kegiatan inti

Berdasarkan pemetaan kompetensi peserta yang diperoleh dari hasil Pre Test maka tim melakukan kegiatan pelatihan dengan sangat perlahan dan berorientasi pada penguasaan peserta bukan pada jumlah materi yang akan disampaikan. Alhamdulillah dengan kerjasama tim dan masyarakat dengan waktu kegiatan 4 hari materi yang direncanakan dari awal bisa tercapai.Kegiatan dimulai dengan sesi teori tentang system bahan bakar EFI.

Berikut dokumentasi selama kegiatan teori berlangsung yang bertempat di workshop jurusan TKR SMK N 1 Kec. Luak :
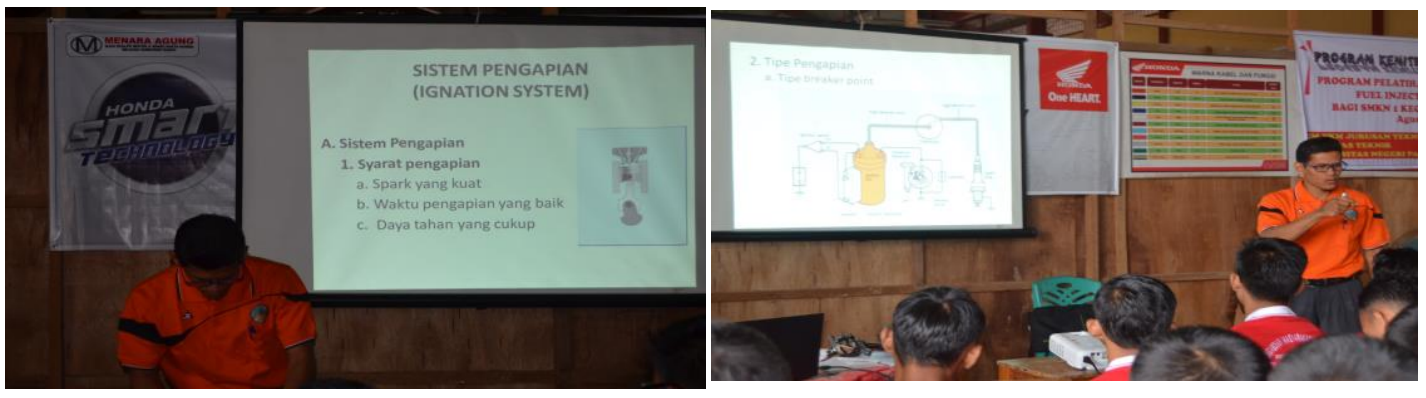

Gambar 6.Peserta mendapatkan materi tentang EFI

Peserta pelatihan secara bergantian melakukan praktikum system bahan bakar EFI. Materi system bahan bakar EFI meliputi: pengenalan sesnsor-sensor, fungi dan cara kerja komponen dan trouble shooting pada system bahan bakar EFI. Dalam praktikum peserta menggunakan cara manual dan menggunakan scan tools dalam mengidentifikasi kerusakan mesin. Di akhir sesi peserta kegiatan juga diberi materi terkait uji emisi kendaraan.

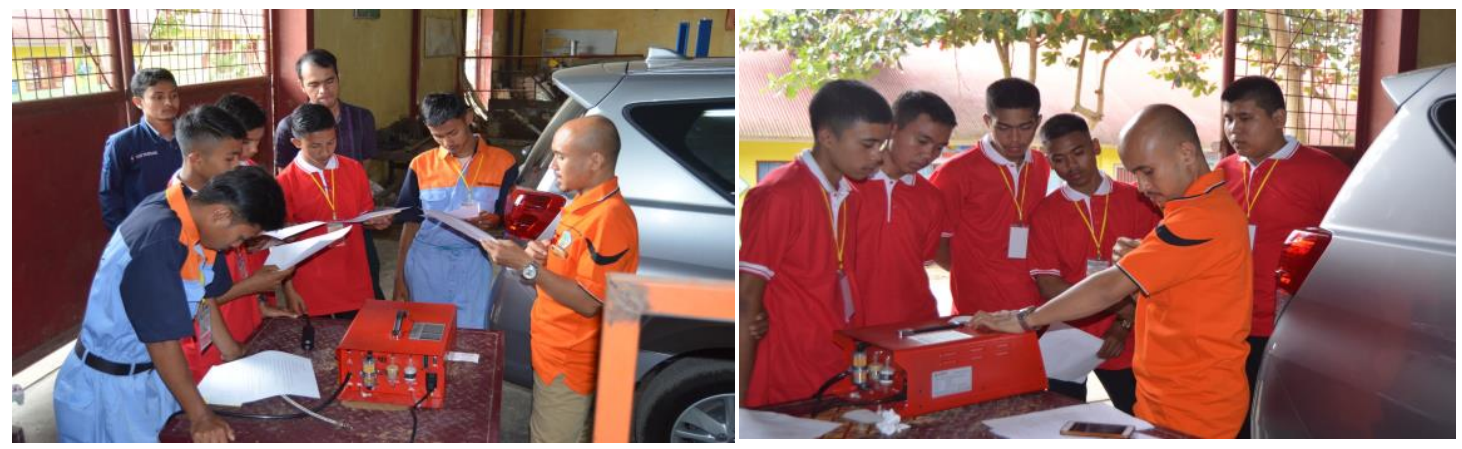

Gambar 7.Peserta praktikum menggunakan scan tool dan four gas analyzer

\section{Evaluasi Kegiatan PKM}

Kegiatan pengabdian ditutup dengan evaluasi kegiatan. Peserta diberi kesempatan untuk mengidentifikasi kerusakan pada mesin secara bergantian. Dari segi teori, peserta juga diberikan soal ujian tulis.
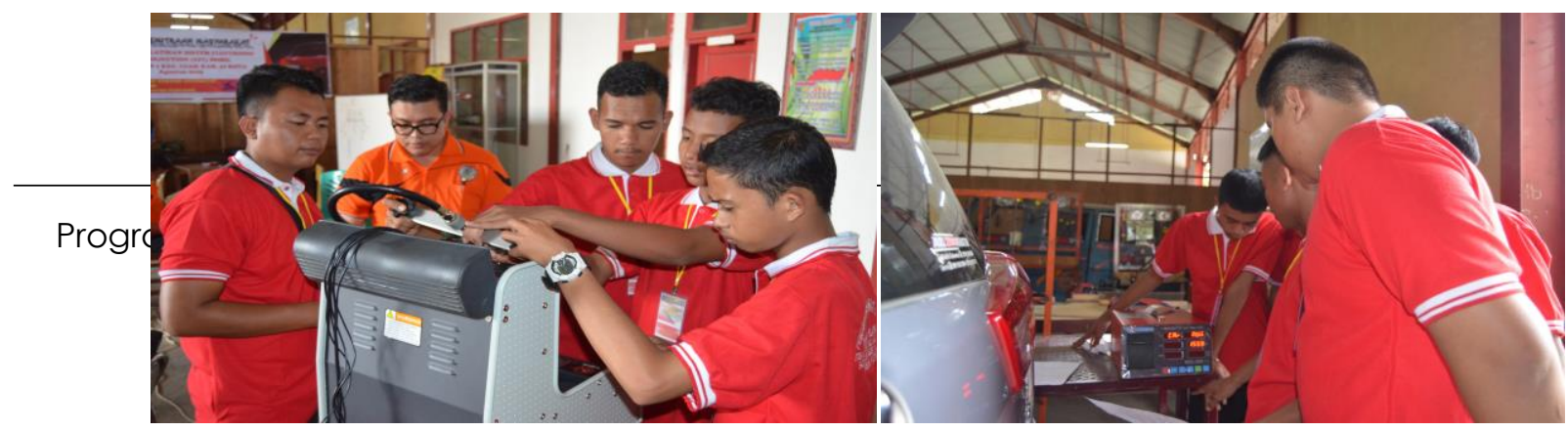
Gambar 8. Evaluasi kegiatan

Berikut hasil rekap evaluasi kegiatan di akhir acara. Dimana terlihat peningkatan pemahaman siswa dan kemampuan siswa dalam praktik system bahan bakar EFI.

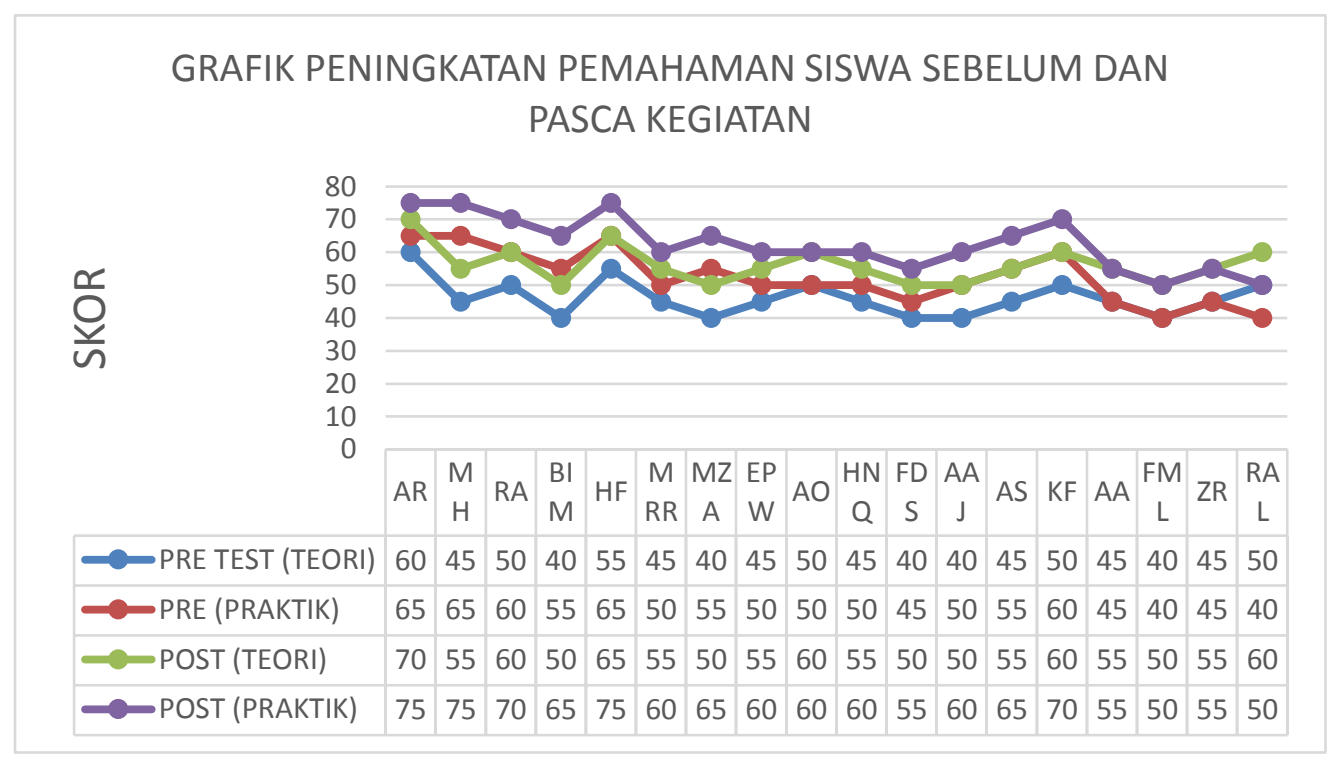

Grafik 2. Grafik peningkatan pemahamn siswa sebelum dan pasca kegiatan

\section{Kegiatan Penutup}

Pada hari ke empat (terakhir) setelah peserta memperoleh seluruh materi pelatihan dan selesai melaksanakan ujian maka dilaksanakanlah penutupan kegiatan. Penutupan kegiatan dilakukan langsung oleh Kepala SMK N 1 Kec. Luak. Berikut dokumentasi acara penutupan. Kegiatan diakhiri dengan sesi foto bersama tim PKM dan peserta pengabdian.

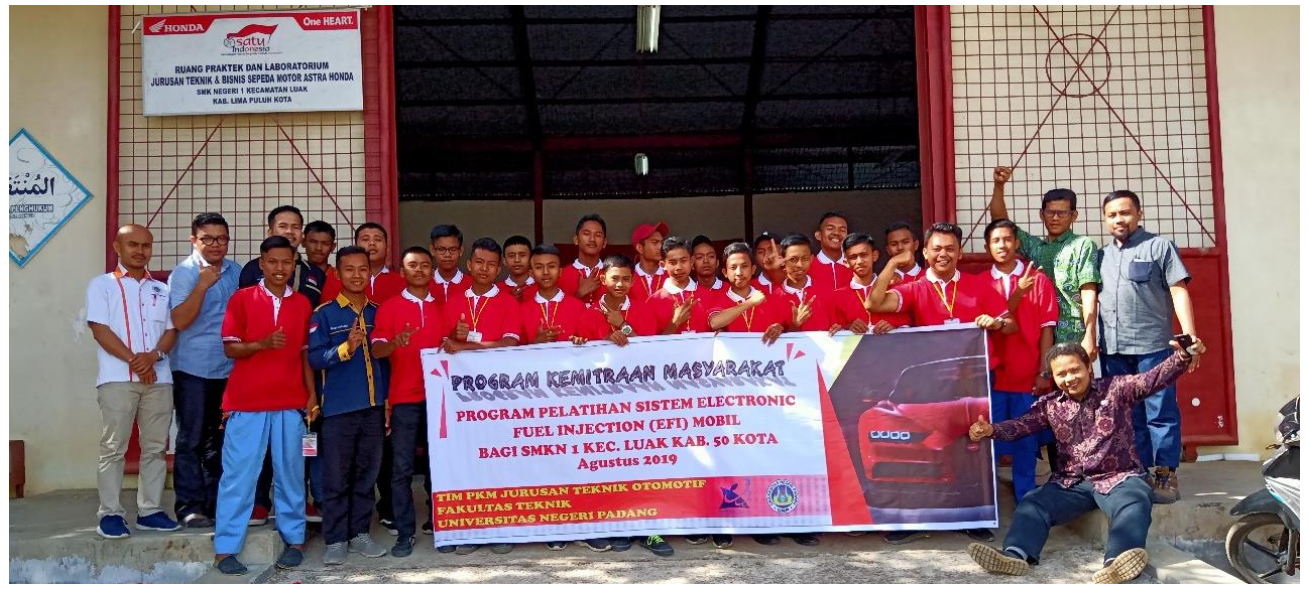


Gambar 9. Sesi foto bersama dalam rangka penutupan kegiatan

\section{KESIMPULAN}

Dari kegiatan PKM yang berlangsung selama 4 hari di SMK N 1 Kec. Luak sangat terlihat antusiasme peserta dalam melaksanakan kegiatan. Bahkan sudah ada rencana lanjutan yang diminta oleh peserta untuk pelatihan selanjutnya terkait system bahan bakar Injeksi. Respon yang baik juga ditunjukan Kepala SMK N 1 Kec. Luak sekolah dimana beliau akan menganggarkan lebih terkait pengadaan peralatan yang menunjang materi ajar system bahan bakar Injeksi.Kendala minimnya peralatan yang tersedia di sekolah menjadi catatan tim pengabdi. Dimana keterbatasan peralatan yang dimiliki sekolah sangat berpengaruh terhadap penguasaan siswa dalam memahami materi tentang system bahan bakar Injeksi (EFI).

\section{DAFTAR PUSTAKA}

Erzeddin Alwi, Nuzul Hidayat, Wanda Afnison, D. Y. (2018). PROGRAM UP-GRADE SKILL SERVICE SEPEDA MOTOR BAGI MEKANIK BENGKEL PEMULA. PAKAR PENDIDIKAN. VOL. 16 NO. 1 JANUARI 2018 (16-21), VOL 16, 16-21.

Fernandez, D., Chandra, R., Maksum, H., \& Afnison, W. (2018). WORKSHOP PENYUSUNAN PENELITIAN TINDAKAN KELAS (PTK). (4).

Hidayat, N., Arif, A., Setiawan, M. Y., \& Afnison, W. (2018). Peningkatan Pengetahuan dan Keterampilan Pemuda Putus Sekolah Melalui Pelatihan Perawatan Berkala Sepeda Motor. INVOTEK: Jurnal Inovasi Vokasional Dan Teknologi, 18(2), 83-90. https://doi.org/10.24036/invotek.v18i2.360

Penyusun, T., Penelitian, L., Pengabdian, D. A. N., Masyarakat, K., \& Masyarakat, K. (2019). Pelaksanaan pengabdian kepada masyarakat. 